\title{
EFFECT OF BASE ISOLATOR ON THE STRUCTURAL RESPONSE OF REINFORCED CONCRETE MULTISTORIED BUILDING UNDER SEISMIC LOADS
}

\author{
Z. Tafheem ${ }^{1}$, T.A. Arafat ${ }^{1}$, A. Chowdhury ${ }^{1}$ and A. Iqbal ${ }^{1}$ \\ ${ }^{1}$ Department of Civil Engineering, Ahsanullah University of Science and Technology, Dhaka, Bangladesh. \\ Date received: 12/03/2017, Date accepted: 13/3/2017 \\ Corresponding author's email: zasiah@ hotmail.com
}

\begin{abstract}
This study investigates the effect of base isolator on the structural responses of multistoried reinforced concrete building under time history earthquake loading. In the present study, two identical six-storied reinforced concrete buildings with one conventional and the other one is base isolated have been modeled. Conventional building has been modeled with fixed support whereas base-isolated building has been modeled incorporating rubber bearing near the base of all columns. Modal analysis has been performed to get an idea of possible mode shapes of the building. After that time history analysis has been performed in order to investigate the effect of seismic loading on the building structure with respect to time. The structural responses of time history analysis such as time period of different modes, storey displacements, storey acceleration, and base shear have been obtained from both conventional and base-isolated buildings. Finally, a comparative study of structural responses has been carried out between those two structures. It has been found that fundamental time period of base-isolated building is increased by $28 \%$ compared to conventional building. Moreover, base shear value of the base-isolated structure is reduced by $69 \%$ and top storey acceleration is decreased by $75 \%$ compared to conventional building. This study reveals that isolation system reduces seismic responses significantly.
\end{abstract}

Keywords: Base isolator, rubber bearing, modal analysis, time history analysis.

\section{INTRODUCTION}

$\mathrm{T}$

HE term base isolation means that the structure such as a building or bridge is separated from its foundation. Now-adays the original terminology of base isolation is more commonly replaced with seismic isolation. The term seismic isolation is more accurate in that the structure is separated from seismic effects. In a seismic isolated structure, base isolation bearings are usually mounted between the structure and its foundation. Relative transverse motion between the structure and the ground is generally allowed in the isolated structure while providing rigid support in the vertical direction. The flexibility between the ground and structure causes the reduction in structural response under seismic vibrations. A base isolation system works by lengthening the fundamental time period of structure which reduces the acceleration. Most importantly, inertia forces that generally develop due to seismic vibration are proportional to building mass and the earthquake ground acceleration. The lateral movement of a seismic isolated structure has been illustrated in Figure 1. As ground acceleration increases, the strength of the building must be increased to avoid structural damage. Base isolation systems attempt to reduce the demand rather than increase the capacity. It is not possible to control the earthquake but it is possible to modify the demand on the structure by preventing the motions being transmitted from foundation into the structure above. It is meant to enable a building to survive a potentially devastating seismic impact through a proper initial design or subsequent modification [1]-[2].

One of the earliest in this regard is the patent by Jules Touaillon of San Francisco filed in the US Patent Office in February 1870 [3]. It described an 'earthquake proof building' which was seated on steel balls which roll inside shallow dishes. In 1891, a base-isolated structure was proposed by Kawai after the Nobi Earthquake. In 1909, a seismic isolation system was proposed by Dr. Johannes Calantarients, an English medical doctor [4]. His idea was utilized in construction of the Imperial Hotel in Tokyo in 1921. After the 1923 Great Kanto earthquake, numbers of patents in Japan were submitted. For instance, the proposal of a double column with damper was proposed [5]-[6]. In 1927, Nakamura proposed a system which consisted of several columns under a ground floor slab with around 15 meters length to the depth of the soil under the structure utilizing dampers at the joint points of the ground floor slab and these columns. In 1968, a building in Macedonia was built on hard rubber blocks. Soon after that, in 1969 a primary school in Yugoslavia was built on rubber bearings as base isolation for strong earthquakes [7]. In another study, innovative simplified design procedures were established for two types of isolator (i.e. lead rubber bearing and high damping rubber bearing) incorporated in multi-storey building structures [9]. In addition, to be acquainted with the optimal isolation system, different seismic base isolation systems were investigated on the dynamic response of multi-storey buildings under seismic loading [10]. Another study described the properties of lead- 


\title{
Journal of Civil Engineering, Science and Technology
}

\author{
Volume 8 Issue 1 April 2017
}

rubber hysteretic bearing together with its behavior under various loading conditions [11]. Numerical investigation has been carried out to analyze the effectiveness and the economic suitability of seismic isolation, using elastomeric isolators and sliders in reinforced concrete buildings [12]. Design procedures for lead rubber bearing was also presented in a study for earthquake resistant design of buildings [13]. A study revealed the differences caused by the use of different codes in the dynamic analysis of multistoried RC building along with fixed and isolated base conditions. [14] A review study summarized current practices, described widely used seismic isolation hardware and chronicles the history and development of modern seismic isolation systems using shake table testing of isolated buildings [15]. The behavior of base-isolated structures with two different types of isolation systems (lead rubber and friction-pendulum isolators) was compared with each other and also compared with fixed base structures in terms of base shear, story displacements, story drift, plastic hinges for different design periods and earthquake motions [16]. Moreover, the effects of base isolation on structures located on soft soils and near active faults were investigated using dynamic analysis procedure [17]. The effect of base isolation system in two different structures (symmetrical and non-symmetrical school buildings) was explored and seismic responses of fixed-base and base-isolated conditions were also compared [18]. A new computational method for system identification was proposed for obtaining insight into the linear and nonlinear structural properties of base-isolated buildings [19]. A case study was taken into consideration for both with and without base isolation systems in order to observe dynamic behavior of such structures under seismic loads [20]. An existing building model with base-isolated conditions needs to be investigated under real earthquake vibration in order to learn about the effect of base isolator on the structural responses in a real life situation. This necessitates the study presented in this paper.

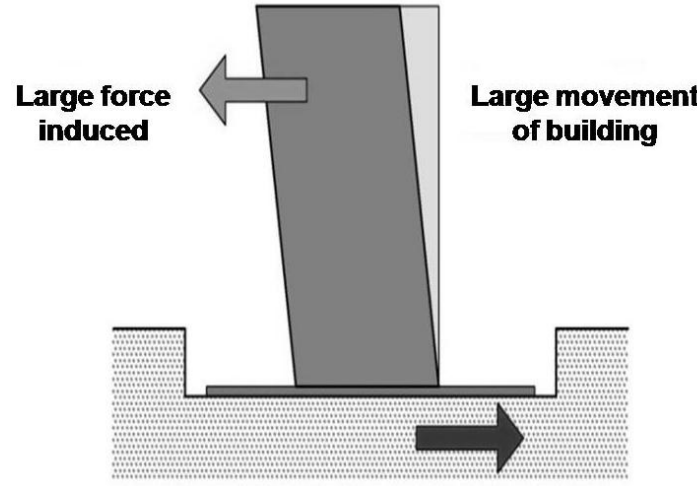

(a) Conventional Building

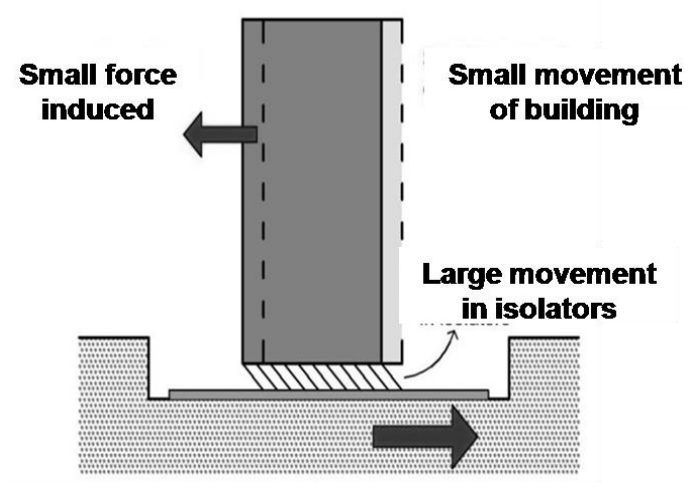

(b) Base-isolated Building

Figure1. Principles of conventional and base-isolated building structures

In the present study, two six-storied reinforced concrete buildings have been modeled using software package ETABS. One of them has been modeled with fixed support at the base and another model incorporated rubber bearings near the base of the columns. After that time history analysis has been performed to understand the effect of seismic loading on the structural responses throughout the loading period. The analysis results of time period, storey displacement, storey acceleration, base shear etc. were obtained from modal and time history analysis for both conventional and base-isolated buildings. Finally, a comparative study has been carried out to ascertain the influence of base isolator on the structural responses.

\section{METHODOLOGY}

For modeling, material properties used for the structure are given in Table 1. Normal weight concrete has been chosen for the buildings in the model.

Table 1. Material Properties

\begin{tabular}{|c|c|c|c|c|c|}
\hline $\begin{array}{c}\text { Name of the } \\
\text { Material }\end{array}$ & \multicolumn{4}{|c|}{ Concrete } & Steel \\
\hline $\begin{array}{c}\text { Material } \\
\text { Properties }\end{array}$ & $\begin{array}{c}\text { Weight Per Unit } \\
\text { Volume }\end{array}$ & $\begin{array}{c}\text { Modulus Of } \\
\text { Elasticity }\end{array}$ & Poisson's Ratio & $\begin{array}{c}\text { Compressive } \\
\text { Strength }\end{array}$ & Yield Strength \\
\hline Unit & $\mathrm{N} / \mathrm{mm}^{3}\left(\mathrm{k} / \mathrm{in}^{3}\right)$ & $\mathrm{MPa}(\mathrm{ksi})$ & -- & $\mathrm{MPa}(\mathrm{ksi})$ & $\mathrm{MPa}(\mathrm{ksi})$ \\
\hline Values & $\begin{array}{c}2.356 \times 10^{-5} \\
\left(8.68 \times 10^{-5}\right)\end{array}$ & $20,000(2900)$ & 0.2 & $27.58(4)$ & $413.69(60)$ \\
\hline
\end{tabular}

In the present study, two structural models of six-storied conventional and base-isolated residential buildings have been 


\title{
Journal of Civil Engineering, Science and Technology
}

\author{
Volume 8 Issue 1 April 2017
}

modeled and analyzed using structural analysis and design software package ETABS V.15 [8]. The conventional building has been modeled with fixed support at the base and the base-isolated building has been modeled incorporating rubber bearings near the base of the columns. Those models included structural components such as RC columns, beams (i.e. grade beams, floor beams, stair beams etc.), shear walls for lift cores and slab. Other structural components were an overhead water tank and a staircase. The dimension along the longitudinal direction was $29.85 \mathrm{~m}$ (97.9ft) and $9.91 \mathrm{~m}(32.5 \mathrm{ft})$ along the transverse direction. The longest bay was $5.97 \mathrm{~m}(19.58 \mathrm{ft})$ in the longitudinal direction and the shortest bay was $4.95 \mathrm{~m}$ $(16.25 \mathrm{ft})$ in the transverse direction. The height of each storey was $3.049 \mathrm{~m}(10 \mathrm{ft})$. The identical column-beam layout plan of the buildings has been shown in Figure 2. A three-dimensional view of the six-storied building model has also been shown in Figure 3.

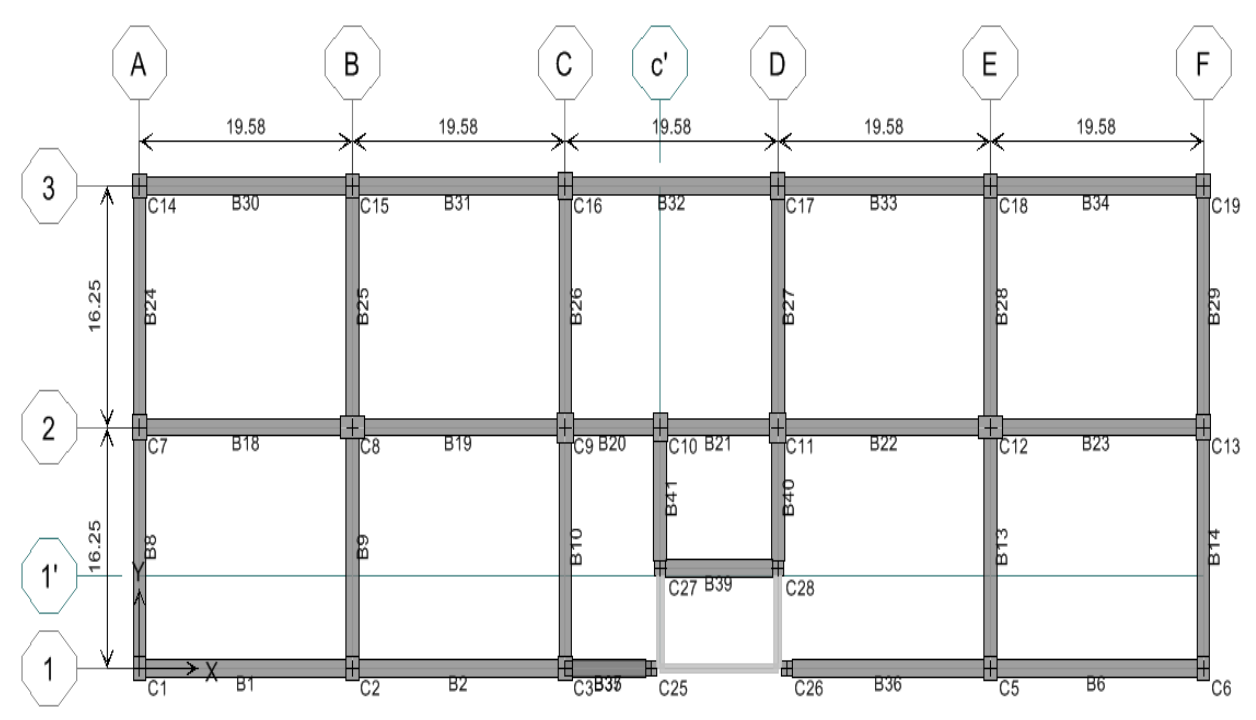

Figure 2. Column-beam layout plan

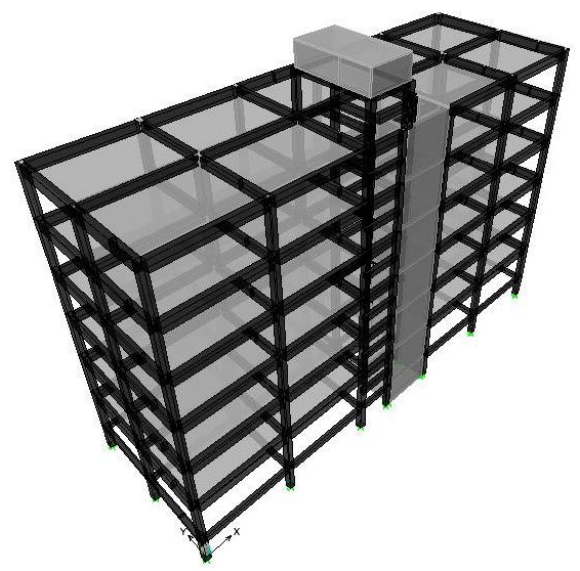

Figure 3. 3D view of six-storied building

Dimensions of columns used for the buildings are given in Table 2. Beam sizes are given in Table 3. In addition, slab thickness was set at $5 \mathrm{in}$.

Table 2. Geometric dimension of columns

\begin{tabular}{lcccccc}
\hline \multicolumn{1}{c}{ Column ID } & $\mathrm{C} 1$ & $\mathrm{C} 2$ & $\mathrm{C} 3$ & $\mathrm{C} 4$ & $\mathrm{C} 5$ & C6 \\
\hline Dimension & $4.27 \times 4.27$ & $4.27 \times 4.88$ & $4.88 \times 7.32$ & $4.88 \times 5.49$ & $3.66 \times 6.1$ & $3.66 \times 3.66$ \\
$\mathrm{~m} \times \mathrm{m}$ (inch $\times$ inch) & $(14 \times 14)$ & $(14 \times 16)$ & $(16 \times 24)$ & $(16 \times 18)$ & $(12 \times 20)$ & $(12 \times 12)$ \\
\hline
\end{tabular}

Table 3. Geometric dimension of beams

\begin{tabular}{ccccc}
\hline Name of Beam & Exterior Beams & Interior Beams & Grade Beams & Stair Beams \\
\hline Width $\times$ Depth $\mathrm{m} \times \mathrm{m}$ & $3.66 \times 7.32$ & $3.05 \times 6.10$ & $3.66 \times 3.66$ & $3.66 \times 4.27$ \\
$($ inch $\times$ inch $)$ & $(12 \times 24)$ & $(10 \times 20)$ & $(12 \times 12)$ & $(12 \times 14)$ \\
\hline
\end{tabular}




\section{Journal of Civil Engineering, Science and Technology}

Volume 8 Issue 1 April 2017

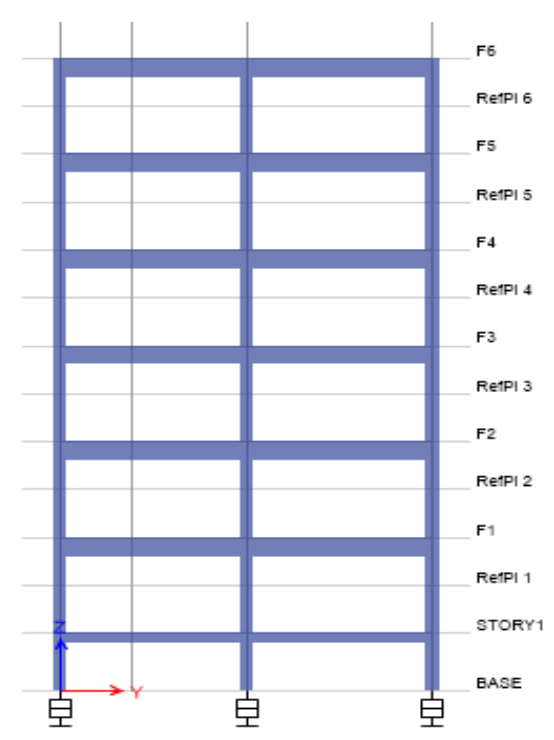

Figure 4. Rubber isolator near base of the base-isolated building

In the case of rubber isolators shown in Figure 4, effective stiffness in vertical direction was kept much greater than that of horizontal direction. However, stiffness was the same in both longitudinal and traverse directions of the building. In addition, linear material properties were considered for this study.

\subsection{MODAL ANALYSIS}

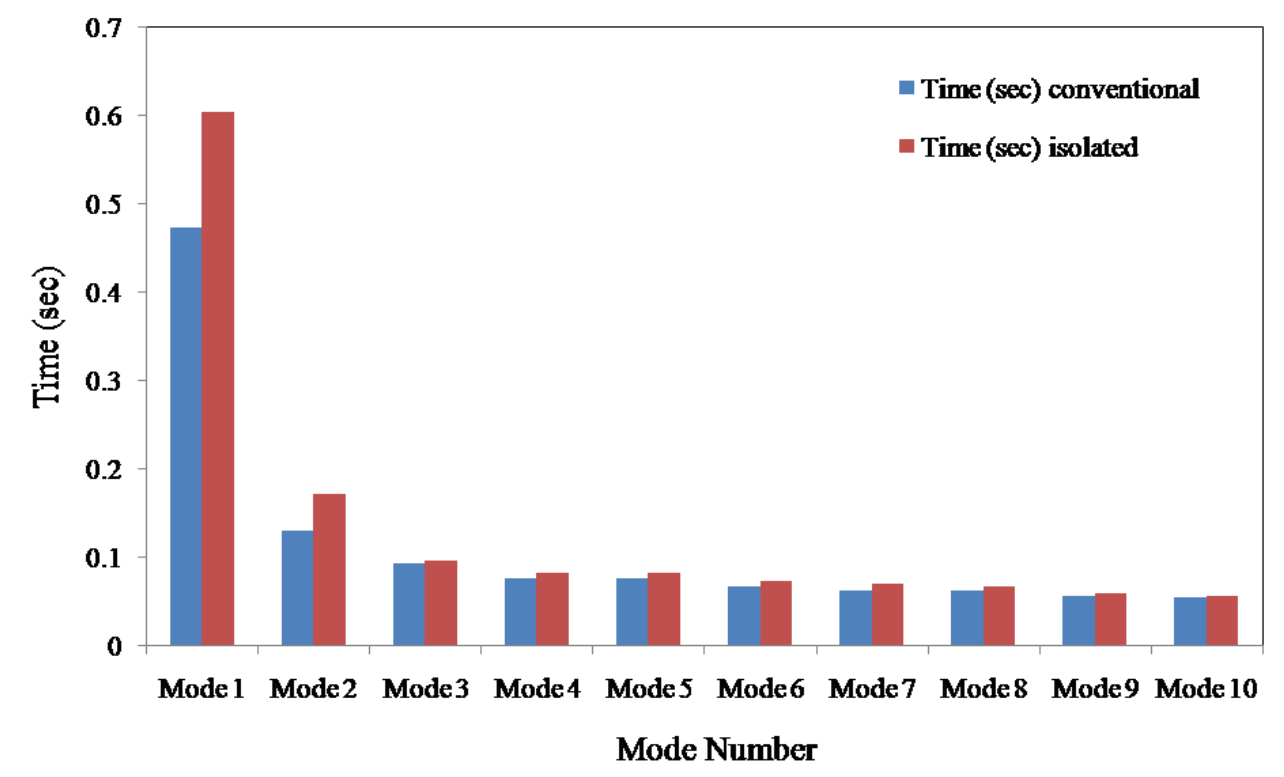

Figure 5. Time period vs. mode number for conventional and base-isolated buildings.

The modal analysis has been done first to get an idea of possible mode shapes of those structures. Those models were then studied under time history analysis technique to observe the response of both conventional and base-isolated buildings with respect to time. This study demonstrated that the overall response was mainly affected by the incorporation of rubber bearings used as base isolators. The predominant time period has been lengthened for the seismic isolated building as logically expected. Figure 4 shows that the fundamental time period of the base-isolated structure has been increased by approximately $28 \%$ compared to the conventional building. For the base-isolated building, time periods of all other modes were also greater than those for the conventional system (Figure 5). For the fixed base situation, fundamental periods were in the range between $0.47 \mathrm{~s}$ and $0.05 \mathrm{~s}$. For the base-isolated system, fundamental periods were in the range between $0.604 \mathrm{~s}$ and $0.055 \mathrm{~s}$. The most important aim of a base isolation system is to increase the fundamental time period of a structure, which can eliminate the devastating first shocks of an earthquake. 


\title{
Journal of Civil Engineering, Science and Technology
}

\author{
Volume 8 Issue 1 April 2017
}

\subsection{TIME HISTORY ANALYSIS}

Seismic loads are generally generated in a structure by imposing ground accelerations. Dynamic time history analysis has been carried out on two buildings. This analysis helped to assess the dynamic performance of the building under earthquake loading. One objective of this analysis was to understand the effect of a base isolator on top storey displacement, acceleration, base reaction and member force of the structure. The linear behavior of the structure has been analyzed during earthquake. In this study, time versus ground acceleration graph of the Northridge earthquake, 1994 obtained from ETABS database has been shown in Figure 6. The selected ground motion is the record at the Rinaldi receiving station during the January 17, 1994 earthquake event in Northridge, Los Angeles. The duration of the ground excitation was approximately 20s with a peak ground acceleration (PGA) of $1.2 \mathrm{~g}$. The ground acceleration record was available at a sample time step of $0.005 \mathrm{~s}$. This seismic data has been taken into account in the present study as the ground acceleration instrumentally recorded was significantly high in an urban area of North America.

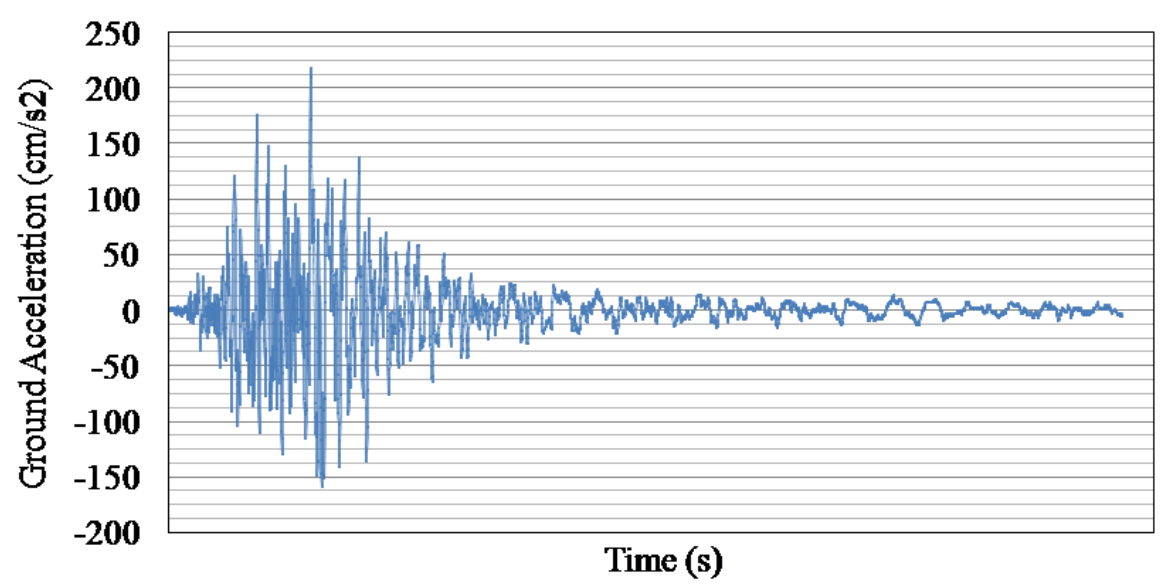

Figure 6. Time history function

\section{RESULTS AND DISCUSSION}

\subsection{STOREY ACCELERATION}

Lengthening of the fundamental time period of a building structure results in reduction of the induced story acceleration and in turn the earthquake-induced inertia forces of the building. As seen in Figure 7, it has been observed that the story accelerations were drastically reduced at all floors when the rubber bearings were used. As seen in Figure 8 , the maximum value of joint acceleration at the top floor in the isolated building was $500 \mathrm{~cm} / \mathrm{s}^{2}$ which was far less than the peak acceleration value of $2000 \mathrm{~cm} / \mathrm{s}^{2}$ obtained from the conventional building. The top story acceleration has been reduced by $75 \%$ due to the incorporation of rubber bearings. The results are in complete agreement with the studies [13] where the top storey's maximum acceleration was reduced by $89 \%$ in the presence of rubber isolators at the bottom.

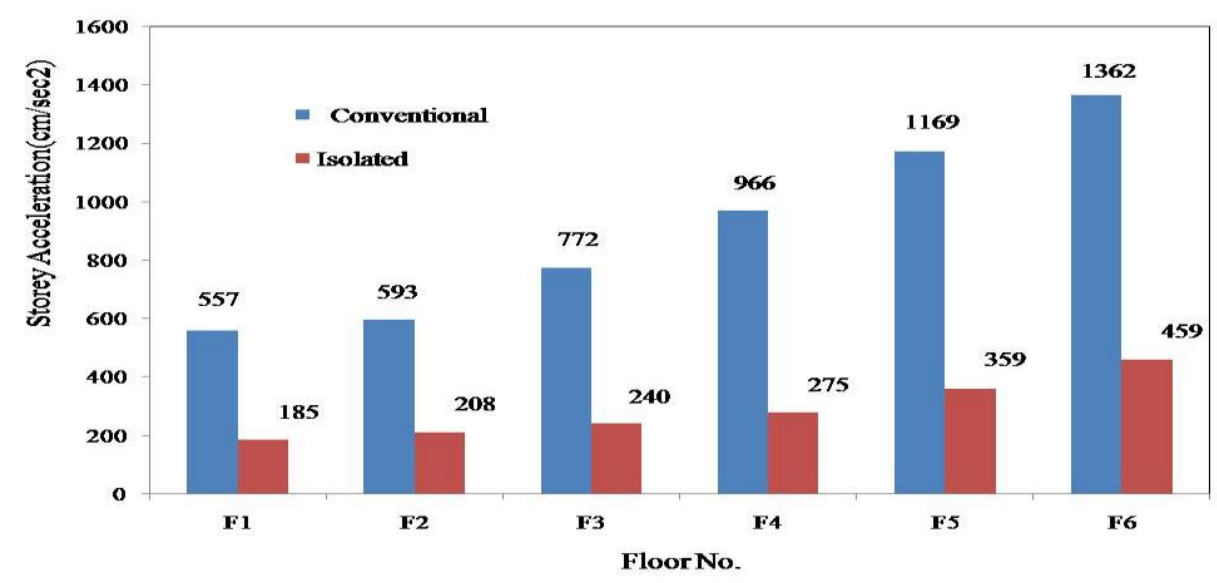

Figure 7. Storey acceleration vs. floor no. for six-storied buildings (pg.53) 


\title{
Journal of Civil Engineering, Science and Technology
}

\author{
Volume 8 Issue 1 April 2017
}

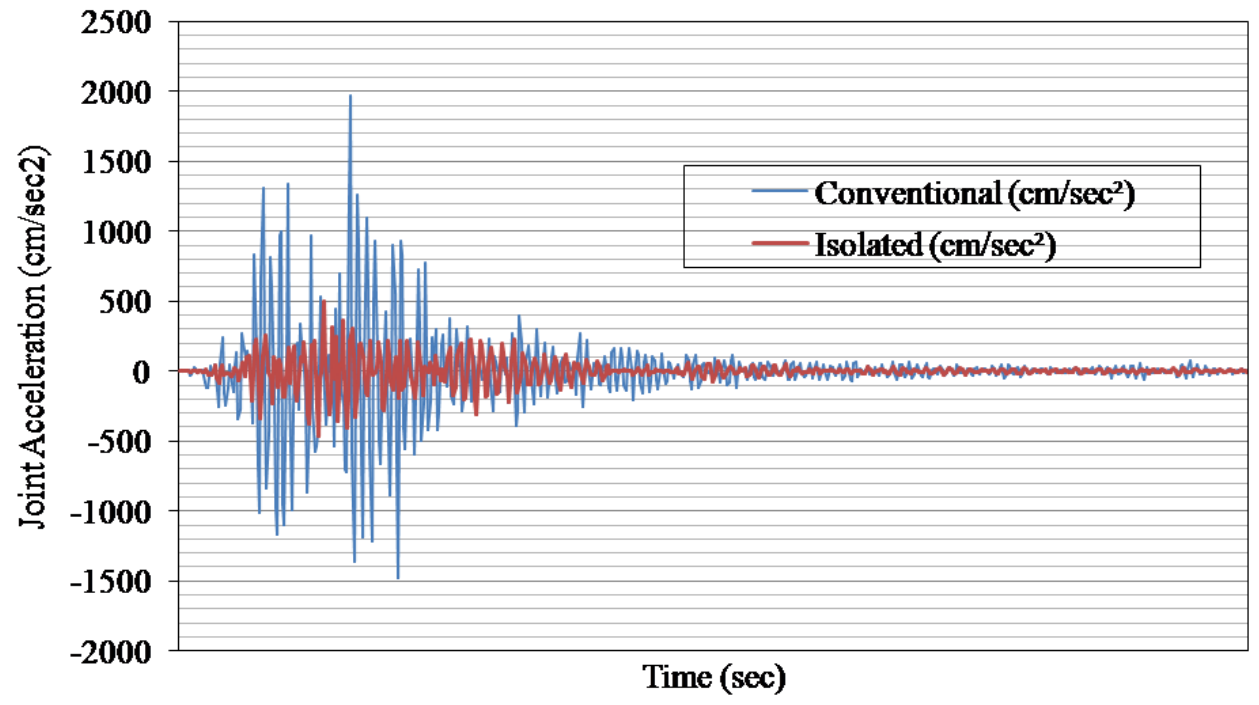

Figure 8. Joint acceleration at top floor vs. time for six-storied buildings

\subsection{Lateral Displacement}

Due to the use of rubber bearings, diaphragm centre of mass displacements at each story were reduced which in turn reduced the impact of earthquake on the structure. From Figure 9, it is clear that only at the first floor was the diaphragm displacement of the base-isolated building greater than that of the conventional model by $17.4 \%$. The result is in close agreement with studies [18] where displacement occurring at the first floor was increased by $19.8 \%$ in the presence of rubber isolators compared to fixed-base structures. However, at all other floors, the diaphragm displacements of the base-isolated building were less than that of the conventional model. As seen in Figure 10, the maximum value of one joint displacement at the top story of the isolated building was $38 \mathrm{~mm}$, far less than the maximum displacement value of $70 \mathrm{~mm}$ obtained from the conventional building. Top story displacement has been reduced about $46 \%$ due to the incorporation of rubber isolators.

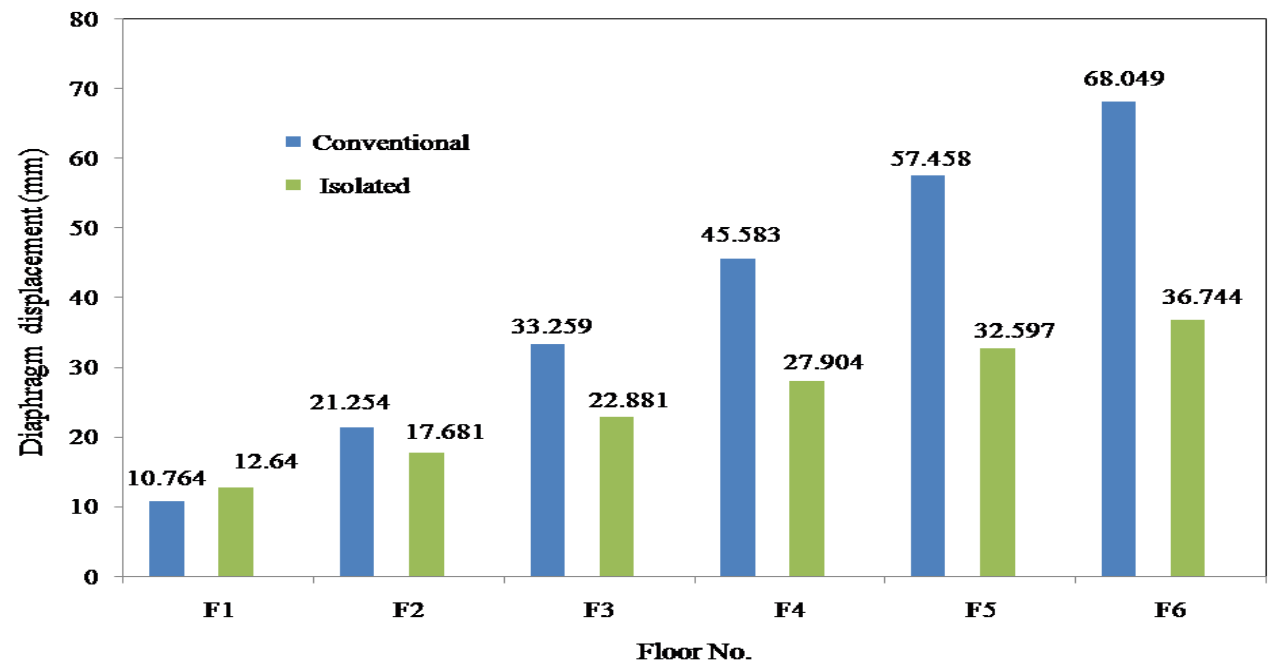

Figure 9. Diaphragm displacement vs. floor number for six-storied buildings 


\title{
Journal of Civil Engineering, Science and Technology
}

\author{
Volume 8 Issue 1 April 2017
}

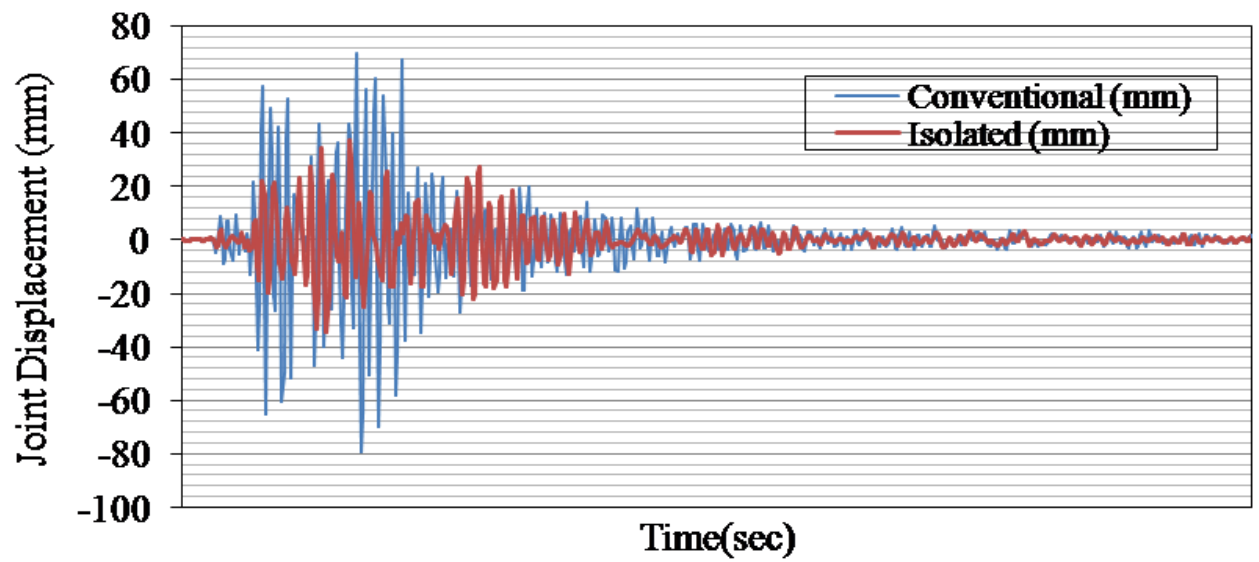

Figure 10. Joint displacement at the top floor vs. time for six-storied buildings

\subsection{Base Shear}

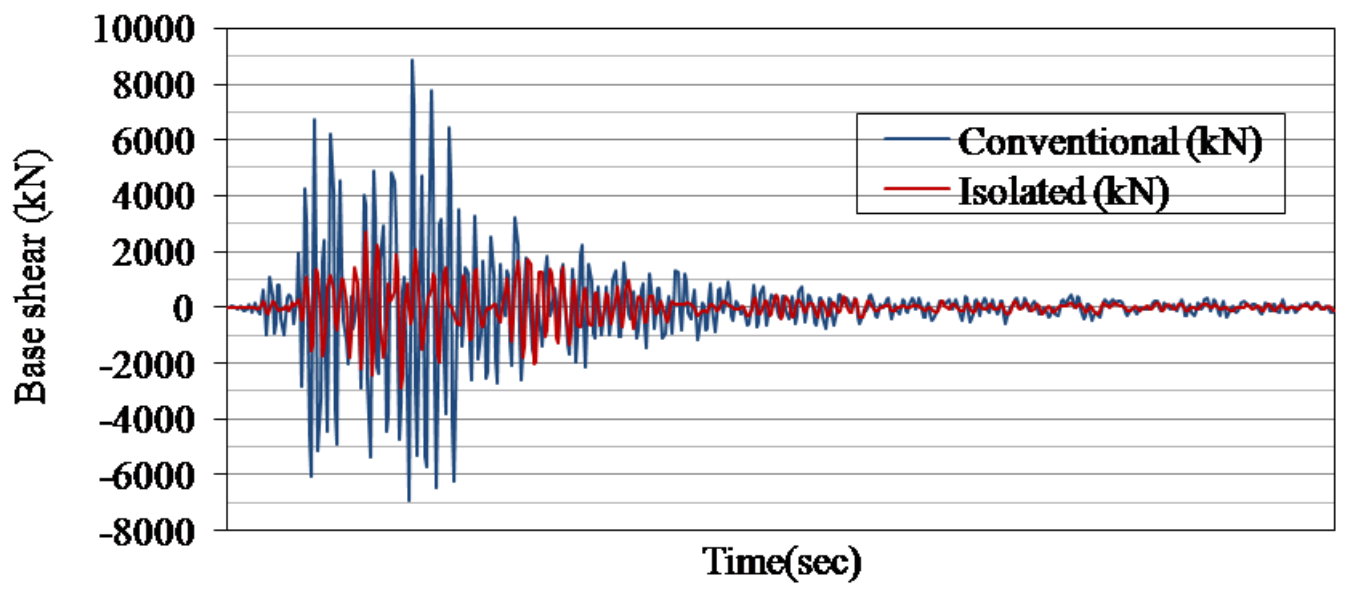

Figure 11. Base shear vs. time for conventional and base-isolated buildings

Rubber isolators reduced induced base shear of the structure during the vibration of an earthquake. As seen in Figure 11, the maximum value of base shear in the isolated building was $2800 \mathrm{kN}$, far less than the maximum shear value of $9000 \mathrm{kN}$ obtained from the conventional building. For the studied building, base shear has been reduced approximately $69 \%$ due to the insertion of a rubber isolator. The results are in complete agreement with studies [14] where base shears were reduced by $63-70 \%$ due to insertion of rubber isolators at the bottom compared to conventional fixed-base structures.

Therefore, reduction in induced structural forces due to seismic isolation systems leads to the design of smaller structural components and consequently considerable reduction in the whole weight of structure, which gives significant reduction in construction costs. It also helps in reducing life cycle cost of a building as safety improvements would reduce repair costs after an earthquake.

\section{CONCLUSIONS}

The findings of the present study are as follows:

- Fundamental time period of the base-isolated structure has been increased by $28 \%$ in comparison to the fixed-base conventional structure.

- Adding rubber bearings to the base-isolated building has significantly increased first floor displacement by $17.4 \%$.

- Top storey acceleration of the structure has been decreased by $75 \%$ by use of a rubber isolator.

- The value of base shear in the base-isolated building has been reduced by $69 \%$ compared to the conventional building.

Hence it can certainly be said that under seismic vibration, the structural response of a base-isolated structure is greatly reduced because of the increase in flexibility provided by the base isolation system which is beneficial for the structure as far as safety is concerned. The efficacy of a seismic isolated system depends on the characteristics of input seismic vibrations, the properties of the isolation devices and the superstructure. Therefore, it is necessary to do a comprehensive study to have an idea of the efficiency of a particular base isolation system according to the particular seismic map of an area and the 


\title{
Journal of Civil Engineering, Science and Technology
}

\author{
Volume 8 Issue 1 April 2017
}

characteristics of potential earthquakes. The main advantage of using a base isolation system is that due to the flexibility of the system, less structural damage would occur during an earthquake. As a result, seismic isolation has been found to be a viable solution for many earthquake prone areas and its development process will continue over many years.

\section{REFERENCES}

[1] T.A. Arafat, A. Chowdhury, and S.M.A. Iqbal, 2015, The effect of base isolator on RC multistored building structure under seismic loading, B.Sc. Thesis, Department of Civil Engineering, Ahsanullah University of Science and Technology, Dhaka, Bangladesh.

[2] Z. Tafheem, T. Ahmed, A. Chowdhury and A. Iqbal, Seismic isolation systems in structures- the state of art review, $11^{\text {th }}$ Global Engineering, Science and Technology Conference, Dhaka, Bangladesh, Dec 2015.

[3] I. G. Buckle, Passive control of structures for seismic loads, $12^{\text {th }}$ World conference on earthquake engineering, 2000.

[4] F. Naeim, and J.M. Kelly, 1999, Design of seismic isolated structures: from theory to practice, John Wiley and Sons, Inc. Design issues for baseisolated bridges: The 1997 Revised.

[5] M Y. Nakamura, M. Saruta, A. Wada, T. Takeuchi, S. Hikone, and T. Takahashi, 2011, Development of the core-suspended isolation system, Earthquake Engineering and Structural Dynamics, pp. 429-447.

[6] M Y. Nakamura, T. Hanzawa, M. Hasebe, K. Okada, M. Kaneko, and M. Saruta, 2011, Report on the effects of seismic isolation methods from the 2011 Tohoku-Pacific earthquake, The Journal of the Anti-Seismic Systems International Society, 2(1).

[7] A.B.M.S. Islam, M.Z. Jumaata, R. Hussain, and M.A. Alam, 2013, Incorporation of rubber-steel bearing isolation in multi-storey building, Journal of Civil Engineering and Management, Vol.19(1).

[8] ETABS nonlinear Version 15.2.0, Extended 3D analysis of the building systems, Computer and Structures Inc., Berkeley, California, USA.

[9] A. B. M. S. Islam, M. Jameel, M. A. Uddin and S. I. Ahmad, 2011, Simplified design guidelines for seismic base isolation in multi-storey buildings for Bangladesh National Building Code (BNBC), International Journal of the Physical Sciences, Vol. 6(23), pp. 5467-5486.

[10] A. B. M. S. Islam, M. Jameel and M. Z. Jummat, 2011, Study on optimal isolation system and dynamic structural responses in multi-storey buildings International Journal of the Physical Sciences, Vol. 6(9), pp. 2219-2228.

[11] W.H. Robinson, 2011, Lead-rubber hysteretic bearings suitable for protecting structures during earthquakes, Seismic isolation and protection systems, Vol. 2(1), pp.5-19.

[12] P. Clemente and G. Buffarini, 2010, Base isolation: design and optimization criteria, Seismic isolation and protection systems, Vol. 1(1), pp.18-39.

[13] G. Warrier, K. Balamonica, K.S. Kumar, Dhanalakshmi, 2015, Study on laminated rubber bearing base isolators for seismic protection of structures, International Journal of Research in Engineering and Technology, Vol.4(2), pp.466-476.

[14] N.R. Chandak, 2013, Effect of base isolation on the response of reinforced concrete building, Journal of Civil Engineering Research, Vol.3(4), pp.135-142.

[15] G. P. Warn, and K. L. Ryan, 2012, A review of seismic isolation for buildings: historical development and research needs, Buildings, Vol.2, pp.300325.

[16] S.M. Kalantari, H. Naderpour and S.R. H. Vaez, Investigation of base-isolator type selection on seismic behavior of structures including story drifts and plastic hinge formation, The $14^{\text {th }}$ World Conference on Earthquake Engineering, October 12-17, 2008, Beijing, China.

[17] S.J.Patil, G. R. Reddy, 2012, State of art review -base isolation systems for structures, International Journal of Emerging Technology and Advanced Engineering, Vol.2(7), pp.438-453.

[18] D.E. Nassani, and M.W. Abdulmajeed, 2015, Seismic base isolation in reinforced concrete structures, International Journal of Research Studies in Science, Engineering and Technology, Vol.2(2), pp. 1-13.

[19] C. Xu, J. G. Chase, and G. W. Rodgers, 2014, Physical parameter identification of nonlinear base-isolated buildings using seismic response data, Computers and Structures, 145, pp. 47-57.

[20] H. Monfared, A. Shirvani, S. Nwauban, 2013, An investigation into the seismic base isolation from practical perspective, International Journal of Civil and Structural Engineering, Vol.3(3), pp. 451-463. 